\title{
UMA REVISTA ILUSTRADA: A SEMANA E O OLHAR SOBRE A AMAZÔNIA (1917-1923)
}

\author{
Raimundo Nonato de Castro \\ Instituto Federal de Educação, Ciência e Tecnologia do Pará - IFPA, Brasil \\ castro_nonato@hotmail.com
}

\begin{abstract}
RESUMO: O presente artigo tem por objetivo demonstrar a importância de uma das principais revistas de circulação na e da cidade de Belém, da primeira metade do século XX. Destacando, entre outros, a relevância que teve para a formação de opiniões, bem como a circulação de ideias e informações. O objetivo do presente é discutir o quanto os temas trabalhados nas páginas dos periódicos serviam para construir no imaginário local aspectos curiosos vinculados aos diversos campos do saber. Vale destacar, o papel desse tipo de produção mostrava-se relevante por ser capaz de constituir em torno da redação desses magazines um corpo intelectual que agiu de várias maneiras apresentando ao público leitor temas que iam além da informação, proporcionando ao mesmo a possibilidade de, pelas imagens, construir uma representação de uma sociedade em ebulição, por isso extremamente ativa, ao debater temas locais e internacionais.
\end{abstract}

Palavras-Chaves: Revista A Semana, Belém, Magazines, Amazônia.

\section{AN ILLUSTRATED MAGAZINE: A SEMANA AND THE LOOK ON THE AMAZON (1917-1923)}

\begin{abstract}
This article aims to demonstrate the importance of one of the leading circulation magazines of and on the city of Belém, in the first half of the 20th century. Explaining among others the relevance it had for the formation of opinions, and the circulation of ideas and information. The objective of the present is discussing how the themes worked on the pages of such journals served to build in the local imaginary curious aspects that were linked to the various knowledge. It is worth mentioning that the role of these types of production was
\end{abstract}


relevant because it was able to constitute around the writing of these magazines an intellectual group that acted in several ways presenting to the reading public subjects that went beyond the information, in that they provided the same ones the possibility of, by images, to construct a representation of a boiling society, therefore extremely active, when discussing local and international themes.

Keywords: Magazines A Semana, Belém, Magazines, Amazon.

Recibido: 20 de septiembre de 2018

Aceptado: 15 de noviembre de 2018

A revista A Semana (1919-1943) mostrou-se como um dos principais meios de informação da cidade de Belém. Fundada por Manuel Lobato ${ }^{1}$ e Alcides Santos, considerados como importantes jornalistas do período, atuaram em diversas frentes, como a política e a imprensa. Apesar da intensidade de suas produções, tem-se poucas informações biográficas, especialmente sobre o segundo. Quanto ao magazine, foi responsável pela divulgação de diversos temas. Neste artigo optou-se por tratar de temas específicos: a política internacional, a moda, a saúde e o humor. A escolha não foi feita ao acaso, isso se deve ao fato de que os redatores estampavam nas páginas do semanário com maior intensidade crônicas, narrativas e imagens. Assim, o artigo ora apresentando foi estruturado obedecendo a forma e a maneira como os textos foram publicados. Primeiro, apresenta-se a análise sobre o conflito mundial, considerando a escrita de Manuel Lobato por demonstrar ser um homem que procurou entender os reflexos da política internacional no Brasil e na região Amazônica. No segundo momento, partimos para a uma análise sobre a moda, e como os cronistas a consideraram como um elemento essencial na construção de um imaginário que procurou associá-la com a ideia de modernidade. A saúde mostrou-se como um tema de destaque, na medida em que, para os redatores, havia uma necessidade de demonstrar que as atividades físicas deveriam fazer parte do cotidiano dos meninos e meninas das escolas

1. Nasceu no Estado do Amazonas a 3 de julho de 1875 e morreu em Belém no dia 4 de novembro de 1960. Veio criança para Belém. Estudou no Colégio Americano, de José Veríssimo e no Liceu Paraense. Cursou Engenharia na Escola Politécnica do Rio de Janeiro, concluiu o curso no Raensslaer Politécnic Institute, em Nova York. Desde jovem mostrou inclinação para o estudo de Literatura, participou das sessões da Mina Literária. Lecionou história na antiga Escola Normal e no jornalismo, desde quando acadêmico: Diário de Notícias, Correio da Manhã, do Rio, nas Revistas Belém Nova e A Semana de Belém. Foi deputado estadual e prefeito do município de Cachoeira do Arari. Sócio fundador da Academia Paraense de Letras e do Instituto Histórico e Geográfico do Pará. A vida literária de Manuel Lobato é fértil e difícil é a escolha de textos de suas crônicas, ensaios e discursos. Escreveu: Bodas de Ouro (novela). Informações disponíveis em: http://www. fcp.pa.gov.br/images/dli/gbpav/espacos/obrasraras/pdf/cov.pdf. Acesso em: 03/11/2018. 
de Belém. Por fim, o humor que foi ao longo do tempo considerado como elemento essencial, capaz de por si, representar em imagens e textos, os problemas, as mazelas e os avanços vividos na cidade, durante os primeiros anos da década de 1920, na capital do Pará.

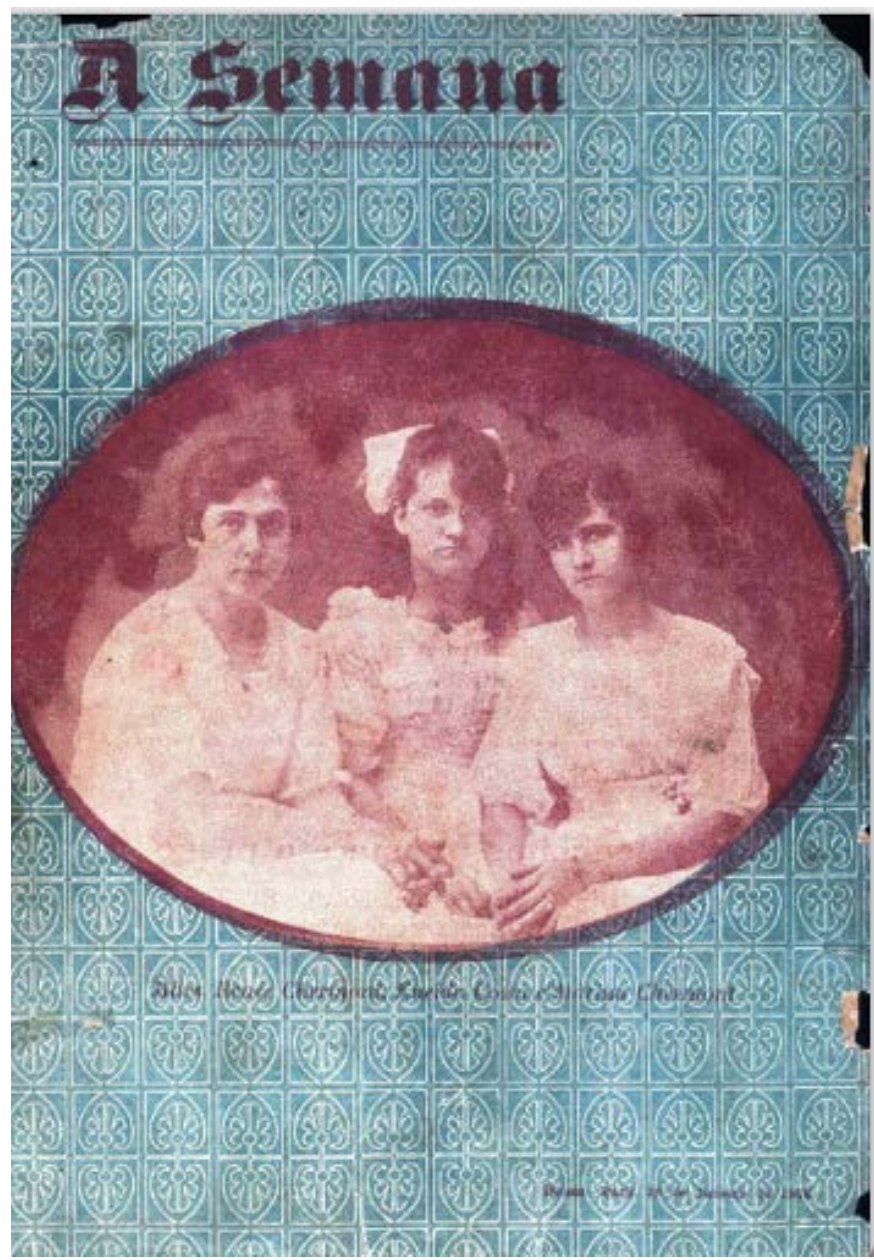

Figura 1. Capa. A Semana: revista ilustrada, Belém, Ano 1, 43, 18/01/1919.

A revista de maior duração e circulação da história de Belém do Pará teve as suas atividades iniciadas na redação do Jornal Folha do Norte, no dia 23 de março de 1918. A data era constantemente lembrada pelos seus proprietários e/ou mesmo pelos confrades de outros periódicos ou revistas de circulação local. A revista efetivamente ganhou corpo no ano de 1919, quando no dia 
18 de janeiro foi publicada a edição de número 43. Chegou ao público leitor com 24 páginas, sem numeração e intitulada revista ilustrada. Tinha como secretário da redação Rocha Moreira ${ }^{2}$. Os valores das assinaturas chamavam atenção, uma assinatura semestral custava 10\$000, enquanto que a anual chegava aos 18\$000. Um número avulso poderia ser comprado pela importância de $\$ 500$. Por fim a revista dava aos seus leitores a possibilidade de comprar um número atrasado pelo valor de $1 \$ 000$, ou seja, o dobro que seria pago por uma edição avulsa. O endereço para as correspondências era o mesmo do jornal Folha do Norte, situado na rua da indústria, $n^{\circ} 33$, área do centro comercial de Belém.

Considerando que os números da revista eram postos em circulação todos os sábados, no turno da tarde, traziam nas suas páginas os mais variados temas. Os que ganhavam destaque estavam relacionados com o cotidiano da cidade. Em especial, a moda, a arquitetura, as artes, a política, o esporte, bem como o que era considerado pelos seus redatores assuntos mundanos. Os proprietários do semanário estavam ligados aos grupos políticos que estavam no poder, mas buscaram garantir a publicação do semanário com o apoio dos patrocinadores, por intermédio dos anúncios, em sua maioria, dispostos nas primeiras e últimas páginas do semanário. As capas do magazine traziam, em sua maioria, fotografias de personalidades locais. O destaque ficava por conta das jovens mulheres solteiras. Já as páginas eram recheadas de poemas, crônicas as quais tocavam na questão do "belo sexo" ${ }^{3}$. Na imagem da página anterior, foram apresentadas três jovens. Uma em especial, merece destaque, pela sua ativa participação na redação da revista. Eneida de Moraes $^{4}$, a moça ao centro, foi secretária da

2. José da Rocha Moreira, nasceu no Ceará e faleceu em Belém do Pará. Nets cidade desenvolvida seus estudos. Foi redator da Folha do Norte e da revista $A$ Semana, colaborando permanentemente na Belém Nova, revista que encampou a Semana Modernista de São Paulo. Publicou vários livros como: Brocatellos; Versos pagãos, Pompas; Pan; entre outros. Informações disponíveis em: http://www.fcp.pa.gov.br/images/dli/gbpav/espacos/obrasraras/ pdf/cov.pdf. Acesso em: 03/11/2018.

3. Expressão muito comum utilizada nas páginas dos periódicos, do final do século XIX e início do XX, em referência as mulheres.

4. Eneida de Moraes nasceu em Belém do Pará no dia 23 de outubro de 1904. Jornalista, escritora, foi uma das mais profundas conhecedoras do carnaval brasileiro. Formada em odontologia, logo trocou seu consultório para se tornar colaboradora em jornais e revistas. A paixão pelas letras levou-a a organizar grupos de escritores para discutir literatura em vários cantos do Brasil. O ano de 1929 marcou a estreia como autora, com o volume de versos "Terra Verde". Três anos depois ela entra na militância política. Presa em 1935, por defender principalmente a inclusão social, é mandada para a Casa de Correção do Rio. Sua passagem por lá despertou a curiosidade do escritor Graciliano Ramos. Preso, também, por causa de suas ideias políticas, ele indagava aos amigos "...quem é aquela mulher de voz forte e poderosa". O interesse se transformou em admiração e rendeu a Eneida a imortalidade no livro "Memórias do Cárcere". Mesmo tendo passado por tantos percalços, a autora não perdia seu encantamento pelo carnaval. Dizia ela: "É no carnaval 
revista e teve uma produção relevante, principalmente, ao construir narrativas relacionadas ao carnaval ${ }^{5}$. No início do século $X X$, as fotografias ganharam importância considerável, porque a maneira como as imagens fotográficas foram dispostas demonstravam a relevância das mesmas. Primeiro havia de certo uma possibilidade de ver o seu rosto estampando numa revista de grande circulação. Apresentando as moças de família aos possíveis pretendentes. E segundo mantinha a ideia de que a elite ocupava um lugar central em relação à circulação de imagens na cidade de Belém.

\section{Semana internacional: o contexto pós-guerra}

A maneira como os redatores e proprietários se comportavam demonstra a necessidade de reforçar o imaginário relacionado a importância da revista A Semana para a história da Amazônia. Na medida em que os temas estavam em conexão com os debates locais, nacionais e internacionais. Isso é relevante porque os primeiros números publicados em forma de revista apresentaram a coluna assinada pelo seu proprietário e intitulada "A Semana". Manuel Lobato destacava nas suas crônicas os dessabores vividos na Europa após primeira Guerra Mundial. Como jornalista, o redator procurava lembrar a maneira como as fronteiras estavam sendo constituídas com as punições trazidas pelos países considerados vencedores no conflito armado.

Para se ter ideia, na edição da revista publicada, em 01 de março de 1919, Manuel Lobato escreveu que a sociedade não deveria ter gradações nem categorias especiais, pois os diálogos na Europa enfatizavam a questão dos países neutros ou aliados. Na verdade, dever-se-ia buscar uma paz universal na qual todos estariam na condição de igualdade. Neste sentido, destacou a relevância dos países aceitarem fazer parte da Liga das Nações, com isso, não deveria prevalecer os interesses das grandes potências. Lobato, assim se posicionava, considerando que na "própria formação do congresso da paz os serviços prestados por países como a Bélgica, Portugal e Sérvia, foram deixados de parte" ${ }^{\prime 6}$,

que todas as fronteiras sociais desabam - pretos, brancos, cafuzos, caboclos, todos em confraternização durante o reinado momesco". Essa festa e suas mudanças estão registrada no livro "História do Carnaval Carioca", que virou leitura obrigatória para quem quer conhecer um pouco mais sobre a folia. Foi homenageada pela Escola de Samba Acadêmicos do Salgueiro, do Rio de Janeiro, que, em 1984, teve como tema do samba enredo "Eneida, Amor e Fantasia". Em Belém, o Império de Samba "Quem São Eles?" Dedicou também a ela o samba-enredo. A autora faleceu em abril de 1971, na cidade do Rio de Janeiro. Informações disponíveis em: http://www.releituras.com/eneida_menu.asp. Acesso em 06 de setembro de 2017.

5. Sobre o tema e a questão do social ver: CASTRO, Raimundo Nonato de. Do carnaval ao social: a caricatura de Andrelino Cotta - 1919-1928. Temporalidades. V. 7, n. 1 (jan./abr. 2015). Belo Horizonte. UFMG, 2015.

6. LOBATO, Manuel. A semana. A Semana: revista ilustrada. Belém, 01/03/1919. 
de modo que o sacrifício de vidas e dinheiro ficaram quase completamente perdidos.

Ainda segundo Manuel Lobato seria necessário buscar uma certa igualdade nos modos de vida para que todos pudessem se unir nos propósitos pacíficos da Liga das Nações. No entanto, o grande problema, residia no fato de terem sido criados uma espécie de classe, a qual se beneficiava, economicamente, pelos tratados impostos em busca da paz. Vale destacar, Lobato considerou a coligação entre os países armamentistas, contudo, esse posicionamento não garantiria a ordem e estabilidade ao mundo "civilizado". Neste sentido, compreende-se a ideia de civilização relacionada com o ideal de progresso, pensado por Jean Starobinski, que os define como termos "destinados a manter estreitas relações" ${ }^{\prime 7}$, por isso, a ideia de civilização mostra-se representada por diversos estados de aperfeiçoamento sucessivos, por essa razão "civilizar" apresenta-se como um elemento que visa atender aos valores humanos bem como os objetos, buscando, assim, abolir as asperezas e as desigualdades grosseiras, eliminando as atitudes rudes.

A revista, por seu proprietário, trazia aos leitores amazônicos, informações bastante interessantes do ponto de vista da história global, inserindo a região no contexto internacional. Diante disso, permitiu que os homens amazônicos pudessem ter acesso a posicionamentos relevantes sobre o conflito mundial, ou melhor, sobre as consequências do evento para a economia, por exemplo. Destaque-se a intensidade das propostas pelos países armados ${ }^{8}$. Propunham, entre outros, um conjunto de restrições, dentre as quais as demarcações territoriais.

Neste ponto lembrou Manuel Lobato que, enquanto houvesse atitude belicosa entre os países, ou seja, se tratava dos "inimigos", não deveria "marcar a França", por exemplo, até os limites de sua força. Isto é, os países europeus estavam carregados da ideia de revanche tornando a convivência perigosa. A França não estava livre de surpresas, como qualquer outro país europeu, porém o papel desempenhado por alguns estados na tentativa de conciliar as relações entre os povos europeus, fez com que o Brasil na condição de árbitro, ocupasse um lugar importante no contexto global.

Para Lobato o Brasil poderia se vangloriar "agora, mais do que nunca", de ter conseguido fazer "mais uma vez a Europa curvar-se ante de si" ${ }^{\prime \prime}$, adotando o critério da arbitragem para estabelecer a concordância entre os países diver-

7. STAROBINSKI, Jean. As máscaras da civilização: ensaios. São Paulo: Companhia das Letras, 2001. P. 15.

8. Apesar do autor não destacar quais eram os países armados, pela analise historiográfica podemos afirmar que Manuel Lobato fazia referência aos países França, Inglaterra e Estados Unidos. Ver: HOBSBAWM, Eric. A era dos impérios 1875-1914. São Paulo: Paz e Terra, 2012. HOBSBAWM, Eric. Era dos extremos: o breve século XX 1914-1991. São Paulo: Companhia das Letras, 1995.

9. LOBATO, Manuel. A semana. A Semana: revista ilustrada. Belém, 01/03/1919. 
gentes. Ressalte-se que as discussões se relacionavam aos aspectos territoriais. Contudo, acreditava, o proprietário da revista, ao chegar os debates acerca da economia, as controvérsias não seriam solucionadas de modo imediato, inclusive, poderiam conduzir ao mal andamento da Liga das Nações.

Como a proposta dos países americanos, para os europeus, restringia-se à análise das fronteiras, Manuel Lobato destacou que o Brasil por sinal não tinha o que temer, pois os seus limites haviam sido conseguidos com perdas em alguns lugares e equidade em outros, não "Ihe acusando a consciência de excesso ao que Ihe devia a justiça, em qualquer das negociações feitas", caso contrário, o estado brasileiro correria o risco de um dano maior, com as "amizades desvanecedora dos grandes da terra".

Fechou a observação com a seguinte menção:

Em mesa de rico não senta pobre incapaz de lhe prestar serviços grandes e mais de ordem moral que de outra qualidade. Era o nosso papel. Mas a nossa situação não melhorou por já sabermos até onde vai ter o nosso território, o tempo apontará o que nos compete fazer em troca das deferências obtidas... ${ }^{10}$

Manuel Lobato foi enfático ao longo do seu texto sobre a importância do Brasil na intermediação de acordos de paz na Europa. Diante desse quadro, nos questionamos: o que levou Manuel Lobato a fundar uma revista mundana? $\mathrm{O}$ que este homem amazônico procurava construir com as suas análises? Sobre a primeira pergunta, o contexto, vivido na região mostrou a necessidade de uma nova abordagem quanto ao registro das informações. Era uma tendência acompanhar as inovações tecnológicas utilizadas em outras partes do Brasil, como no caso do Rio de Janeiro e São Paulo, onde a quantidade de semanários mostrava uma nova forma de compreender o cotidiano da elite regional. Por seu turno, a segunda questão mostra que as suas análises, conectavam-se com os valores atribuídos aos conceitos relacionados a ideia predominante de progresso e civilização, tanto é assim, que as revistas ao chegarem ao público leitor apresentavam conceitos pelas letras dos intelectuais colaboradores do magazine. E Lobato, enquanto proprietário, tinha na revista um espaço ideal para expor as suas considerações, bem como fortalecer opiniões e contribuindo na divulgação de informações.

\section{Uma revista moderna: moda e carnaval}

No caso de Belém, as informações com teor político ocupavam as páginas dos jornais. Por seu turno, as revistas mostravam-se como mecanismos de divul-

10. LOBATO, Manuel. A Semana: revista ilustrada. Belém, 01/03/1919. 
gação de temas os mais variados, "de informação mais elaborada, anunciando as últimas descobertas sobre as matérias abordadas"11. Um claro exemplo disso ficou por conta da moda, tanto que Rembrandt Junior, na coluna intitulada "Chispas" destacou haver, no Pará, cavalheiros sisudos, graves, "apóstolos da seriedade e escravos da Moral"12, católicos ou protestantes, espíritas ou livres-pensadores, cuja maior glória seria a manutenção do espírito de insurreição contra as modas e os costumes.

Citou como exemplo "o meu amigo Anthero Ribas", que há tempos quando a moda das saias largas compridas era chic, questionava contra "esse bom gosto". Para o autor do texto, a maneira como Ribas se posicionava deixava evidente o seu pensamento "idiota", pois ficava bem as saias longas em meninas de "pernas mirradas", porque escondiam assim, dos olhares dos "elegantes curiosos", o que, segundo Ribas, demonstravam um posicionamento defeituoso, "uma fealdade". Verifica-se com essa abordagem, as severas críticas que este tipo de moda recebeu, também houve quem a considerava boa, assegurando às moças que não tinham pernas grossas a possibilidade de escondê-las dos olhares curiosos, impedindo que os demais falassem mal das meninas desprovidas dessa qualidade.

Para piorar a situação, Rembrandt Junior, lembrou que com a chegada da guerra e, consequentemente, da carestia de vida, a situação levou a uma alta dos preços dos produtos, e também dos tecidos, neste caso, os "tailleur" sempre atentos a situação e para impedir que houvesse aumentos considerados dos vestuários, foram encurtando as saias, desnudando os braços e ampliando os decotes. Aliás, o autor considerou que Anthero Ribas se deleitava ao ver as mulheres vestidas de acordo com os padrões da moda de sua época, "agora berra que tal moda é uma indecência e que inegavelmente caminhamos para o maillot ou para o nu". Ora a justificativa para a evolução da moda, ocorreu pela guerra e pelo aumento dos preços dos produtos, isso pode ter ocorrido, porém, as necessidades das mulheres, tais como correr para pegar o bonde para não chegar atrasada ao trabalho, passou a ser considerado um fator importante na modificação das roupas trazidas pelos "tempos modernos"13. Para Marshall Berman, possivelmente o século XX tenha sido o período "mais brilhante e criativo da história da humanidade"14, pois as constantes modificações trazidas por esse século proporcionaram novos olhares sobre o mundo.

Rembrandt Junior acreditava, diante do cenário, o retorno aos tempos olímpicos, pois a "gaze vaporosa com que as nossas preciosas se enfeitam, apossou-se dos braços; mas no andar em que vimos ela triunfará, e então teremos

11. MARTINS, Ana Luiza. Revistas em revista: Imprensa e práticas culturais em tempos de República, São Paulo (1890-1922). São Paulo: Editora da Universidade de São Paulo: Fapesp, 2008. P. 39.

12. JUNIOR, Rembrandt. Chispas. A Semana: revista ilustrada. Belém. 18/01/1919.

13. JUNIOR, Rembrandt. Chispas. A Semana: revista ilustrada. Belém. 18/01/1919.

14. BERMAN, Marshall. Tudo que é sólido desmancha no ar: a aventura da modernidade. São Paulo: Companhia das Letras, 1986. P. 23. 
apenas as túnicas esvoaçantes, que plasmarão ninfas coroadas de rosas". Vê-se com essas observações, certo exagero na análise, ao destacar a maneira conservadora dos homens diante do cenário apresentado. Vale ressaltar, para o "meu amigo", ele via nas ruas da cidade os trajes femininos, segundo suas considerações, estavam mais para fantasias provocantes, pois afetavam sentidos. Tanto que outro dia "me dizia a puridade": -Sabes? Dancei na soirée do clube X com mlle. N. Ah! menino, que decote e que collo soberbos... dir-se-ia uma graça; há tantos Antheros no Pará!... "15. Se construía no Pará, uma narrativa na qual se valorizava o corpo, mas que desconsiderava as vestimentas, somente quando Ihes convinha, por isso a afirmação do autor.

Voltemos mais uma vez para Berman ao afirmar que a nostalgia de um estilo se apresentava como "sinal de obsolescência"16, no qual há nitidamente uma tristeza nostálgica, por essa razão as dramatizações, quanto às contradições vividas pela sociedade, levavam o homem a questionar os caminhos que o seu mundo encaminhava. Não à toa que a moda, a priori, no Pará, diante das suas transformações, mostrava os caminhos adquiridos pelo corpo feminino aos olhos dos conservadores, ao considerarem a postura das mulheres como ameaçadora da ordem moral. $\mathrm{E}$ foi justamente neste tipo de magazine que a moda se tornou um elemento relevante, pois passaram, os redatores, a ditarem os modelos e as referências as quais as mulheres e seu corpo deveriam ser enfatizados no início do século $X^{17}$.

A forma como os textos eram elaborados relacionavam-se com um certo padrão de sociedade defendido pela elite belenense, ao carregar em seu seio elementos considerados relevantes para a formação de valores os quais se mostravam essenciais para representar a forma como a cidade de Belém passou a ser vista, a partir das páginas do periódico. Com isso, considerando o tema: a moda, como algo além da concepção do vestir, na medida em que produziu parâmetros de representação, ao apresentar certos padrões de intencionalidade, na concepção de Michael de Baxadall ${ }^{18}$ capaz de constituir um modelo no qual a sociedade pudesse ser visualizada. Produzindo concepções capazes de abarcar o modus vivendi local, a partir de uma perspectiva global.

Na edição publicada, em 01 de março de 1919, uma página inteira foi reservada a crônica denominada "A Moda", a autoria do texto ficou por conta de Maria de Magda, além de escrever para o semanário, essa autora, produziu textos e crônicas para os jornais de Belém. Um dado importante ficou por conta

15. JUNIOR, Rembrandt. Chispas. A Semana: revista ilustrada. Belém. 18/01/1919.

16. BERMAN, Marshall. Tudo que é sólido desmancha no ar: a aventura da modernidade. São Paulo: Companhia das Letras, 1986. P. 80.

17. MARTINS, Ana Luiza. Revistas em revista: Imprensa e práticas culturais em tempos de República, São Paulo (1890-1922). São Paulo: Editora da Universidade de São Paulo: Fapesp, 2008.

18. BAXANDALL, Michel. Padrões de intenção: a explicação histórica nos quadros. São Paulo: Companhia das Letras, 2006. 
da intensa participação feminina, não só com seus textos, mas também, com a presença no interior das redações. Aqui temos uma observação bastante interessante, porque as revistas colocavam na ordem do dia temas curiosos por merecerem ser revistos, por isso, os periódicos permitiam um "tipo de leitura fragmentada, não contínua, e por vezes seletiva"19, ou seja, as construções narrativas estampadas nas páginas dos magazines permitiam ao leitor um conjunto de informações de maneira diferentes dos livros e jornais, por exemplo.

Tanto é assim que, Maria de Magda, ao argumentar sobre as festas populares, lembrava terem sido legadas pelo passado, e como conservavam "tradicionalmente, talvez, popular" em razão de ter atravessado várias épocas, o carnaval era tido como a principal herança dessa característica popular. Ainda, na sua opinião nada mais era do que as antigas festas "pagãs a Baco", e mesmo no seu tempo, havia quem "não compreenda em sacrifício a Momo e a Baco"20, a loucura da folia carnavalesca. Por sinal, essa era uma das principais características dos colaboradores, ao relacionar o seu tempo, com os valores da antiguidade e da mitologia clássica. As festas carnavalescas, na cidade de Belém, ganharam uma proporção tão grande, que nos principais estabelecimentos da capital, a quantidade de bailes e participantes era gigantesca. E a intensidade desses eventos, ganhou as páginas dos jornais e revistas da época, demonstrando a sua importância para a sociedade local.

A crônica de Maria de Magda, ganhou um reforço interessante, quando na página ao lado, foi disponibilizado a imagem a seguir. Reforçando a ideia presente no texto. Antes, porém, ao observamos a figura, nos deparamos com uma Colombina imponente, gingante a qual manifesta-se pelo domínio da cena. Ocupando a página inteira, mostra-se senhora da situação. O texto abaixo da figura é relevante, já que considera os elementos comuns da realidade humana, mostrando como eles acompanham o homem, ao longo da sua vida. Contudo com a chegada da folia, aqueles itens associados ao sofrimento e melancolia vestiam-se de contentamento. Por sinal, com o carnaval os males que atormentavam o homem, muitas vezes eram esquecidos, somente retornando com o fim das festas.

Segundo, Maria de Magda nos primeiros anos do carnaval o povo não usava "travestis", ou seja, as variadas fantasias, fazendo uso tão somente de um único modelo, onde predominava as rosas e as guirlandas de verdura à cabeça ou a cintura. Criticava o uso de máscara, "hoje tão usada", as quais deveriam ficar restritas ao teatro. Mas, também, chamava atenção para a meia-máscara, considerando-a elegante para a sua época, porém esse recurso, mal encobria o rosto permitindo, de dentro, um saltar dos olhos ao provocar certo ar misterioso ao portador, por isso, "é, relativamente, moderno". Ao considerar a meia máscara algo moderno, a autora fazia uma digressão histórica, apontando que as "festas brilhantes", e os bailes de

19. MAGDA, Maria de. A moda. A Semana: revista ilustrada. Belém. 01/03/1919.

20. MAGDA, Maria de. A moda. A Semana: revista ilustrada. Belém. 01/03/1919. 
máscaras datavam da República de Veneza, sobre cujos canais as gôndolas "singravam elegantes e ricamente empavesadas, num éter no Carnaval"21.

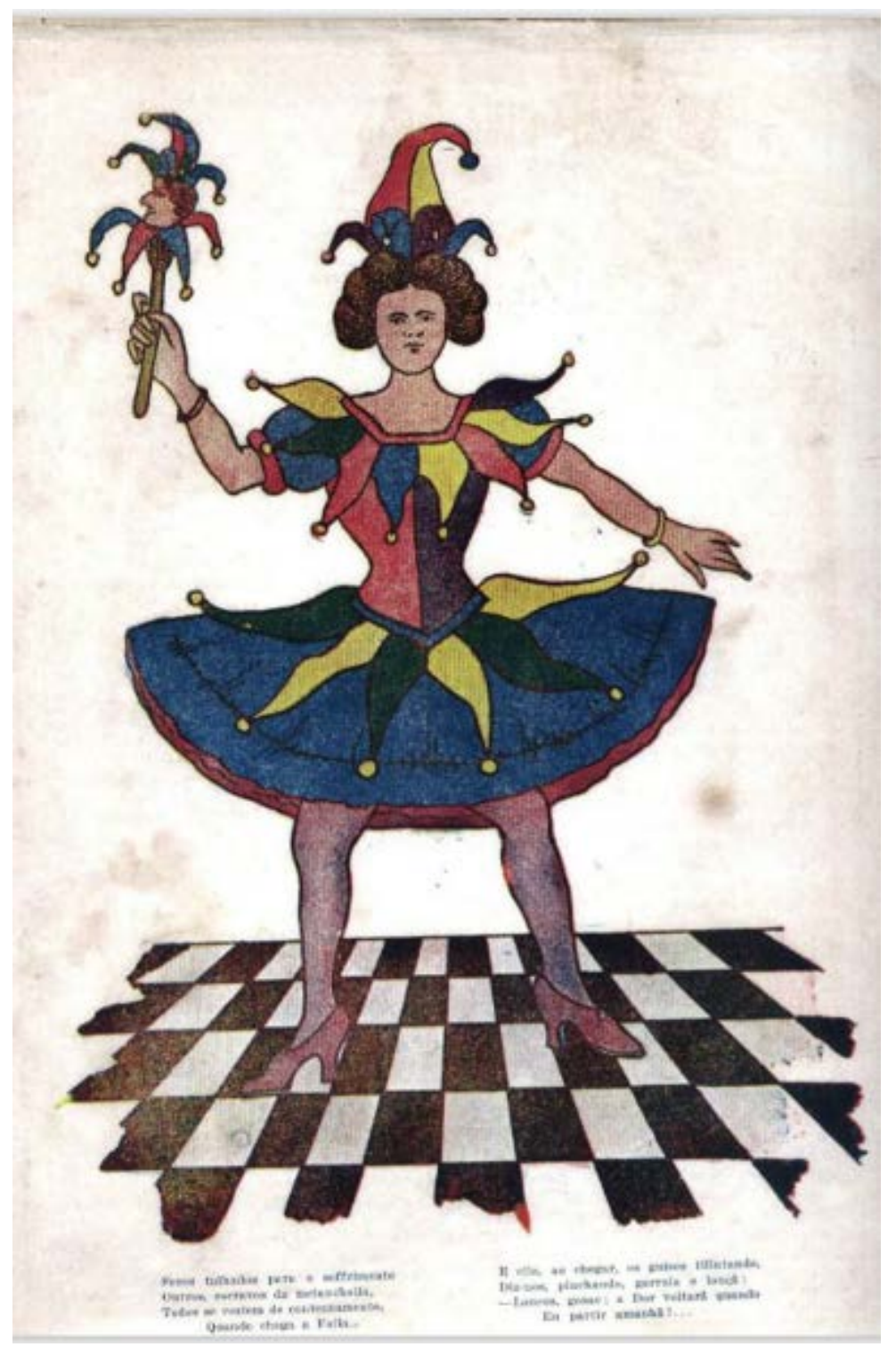

Figura 2. A Semana: revista ilustrada, Belém, Ano 1, 49, 01/03/1919.

21. MAGDA, Maria de. A moda. A Semana: revista ilustrada. Belém. 01/03/1919. 
Para confirmar sua teoria, Maria de Magda afirmou que "todos os historiadores" eram unânimes ao destacar, em Veneza, durante a República, tudo era motivo para as mascaradas. Daí a contínua sucessão de festas "masquées" as quais distraiam o povo da cidade italiana. Muito naturalmente, o Carnaval de "hoje se modificou", embora a sua essência tradicional conservasse, ainda, a mesma forma: "a festa popular, pagã e louca". Isto quer dizer, para Maria de Magda, o carnaval tinha uma história de origem italiana, no entanto, adquiriu novas feições com o passar dos anos, provocando nos seus admiradores certas reflexões, aos quais trabalhavam conceitos como o de modernidade. E no Pará a festa de Momo mostrava-se grandiosa, especialmente, para a elite belenense.

As festas carnavalescas do seu tempo apresentavam dois elementos considerados importantes, o primeiro considerava os aspectos genuinamente populares, pois "é o carnaval das ruas polimorfo, barulhento, bariolé, variado, berrante e exótico das ruas"; e o segundo apresentava-se como elegante, fino, delicado, apenas restrito aos "clubs chics, familiaridades", onde o confete, a serpentina, e o lança-perfume serviam de pretexto a um galanteio "jocoso ou a um madrigal de espírito". No primeiro caso, não havia figurinos nem moda. Tudo servia, desde que fossem berrantes e exagerados, garridos e variados, "farfalhante e estapafúrdio" 22 . Para o segundo, a moda criava estilos e formas, porém transigentes, pois em matéria de fantasia não poderia haver leis nem submissões.

Partindo dessas considerações, a autora afirmava ser difícil a escolha de fantasias, porque, ao contrário do Carnaval popular, onde as vestimentas não eram pré-definidas, nos carnavais elegantes havia algo de sóbrio, chic, luxuoso, escolhido, requintado e distinto. Para Maria de Magda, o bom seria que disso se compenetrassem todos quantos vão as "soirées masquées". Não se veria os "indefectíveis pierrots e pierrettes, cloun e clouness, dominós, etc". ${ }^{23}$, ou seja, as fantasias, consideradas por ela, antiquadas, mas apropriadas à rua e aos casinos seriam valorizadas, de acordo com os padrões defendidos pelos organizadores dos bailes.

Justamente, neste pondo, para a autora, a "soirée masquée" moderna era um "verdadeiro contraste dos folguedos carnavalescos populares", porque na Europa, na América e, sobretudo, em Londres, Paris e New York, os clubs familiares costumavam denominar as suas "soirées" criando, desse modo, uma fantasia única e uniforme, capaz de dar a essas um cunho de distinção extraordinária. Havia assim, os "soirées greco-romanas, turcas, egípcias, chinesas, a Luiz XIV, XV, XVI, Império, Renascença, etc, etc., todas elas de um luxo e de uma elegância incontestáveis". Fora disso, nas "soirées masquées" sem denominação, quer dizer, naquelas onde a fantasia podia ser qualquer uma, é claro que deveria presidir à escolha uma fina e distinta sobriedade, recaindo a preferência nos trajes históricos, "tão exóticos", os quais se prestam a "belas fantasias e modelos", ou

22. MAGDA, Maria de. A moda. A Semana: revista ilustrada. Belém. 01/03/1919.

23. MAGDA, Maria de. A moda. A Semana: revista ilustrada. Belém. 01/03/1919. 
então aos trajes mitológicos e simbólicos, como: "Ceres, Terpsychore, Euterpe, Pomona etc., ou Primavera, Noite, Borboleta, Cysne, etc" ${ }^{\prime 24}$.

Ora, considerava a necessidade de ter uma orientação para os bailes carnavalescos, com o objetivo de evitar os exageros capazes de impedir a valorização do ato, pois sem uma pré-ordenação, as fantasias não teriam um direcionamento e os modelos utilizados causariam aos olhos dos observadores uma verdadeira confusão. Por isso, Maria de Magda enfatizou ainda, "ultimamente", no Rio de Janeiro, num dos salões mais "distintos", houve uma "soirée" romanos, no qual os participantes se fantasiaram de modo a representar os personagens mais célebres dos romances, como: "Chantecler, O conde de Monte Cristo, L'aiglon, Barba Azul, os três mosqueteiros, Manon Lescault, Tosca, etc, etc ${ }^{\prime 25}$. considerou ter sido, na verdade, nem original, muito menos belo, porque houve uma verdadeira confusão, contrastando com o objetivo que seria uma representação do baile romano. Georges Minois ao considerar, as festas carnavalescas realizadas no Império francês, que os homens comuns utilizavam a abstração para "erigir novos ídolos, a pátria, a liberdade, a razão; procuram sacralizar o profano, mostrar o mundo no lugar que destroem os ídolos, invertem a ordem estabelecida e zombam dos valores ${ }^{\prime 26}$. Isto quer dizer, as festas populares procuravam fazer seus participantes e observadores rirem dos excessos, neste sentido, concordamos com Minois ao afirmar que o "riso não acontece por decreto e uma festa sem riso não se caracteriza como popular"27.

Ao concluir a crônica, Maria de Magda destacou ficar feliz caso visse os "nossos clubes, como a Assembleia, Sport e Pará-Club", iniciarem na cidade de Belém essa nova orientação de bailes, "dando-nos, por exemplo, soirées Império, Japonesa, greco-romana, etc." Ficou, pela sua narrativa, a autora na expectativa "até a Mi-Carême", pois para o Carnaval "de agora já não há mais tempo, visto amanhã ser Domingo-Gordo". Finalizou a crônica colocando à disposição dos leitores três estampas fantasias "elegantíssimas" que representam: -1, a "A uva", em musselina de seda branca com "corsclet" verde em forma de folha e cachos de uva bordados sobre a saia; 2, "Borboleta", também em musselina, guarnecida de borboletas bordadas com cinto de ouro e prata, e 3, "A primavera"$^{\prime 28}$ em crepe da China branco, muito simples e flexível.

Mesmo diante dos conselhos dados aos leitores sobre o carnaval e a moda, Manuel Lobato ao escrever uma nova crônica e publicá-la, no dia 08 de março de 1919, lembrava a época destinada aos festejos carnavalescos como tendo sido transportada quase toda em "canoas, pelas ruas de Belém", as festas realizadas na cidade, na opinião do cronista, destacava-se por ser possível mas seria

24. MAGDA, Maria de. A moda. A Semana: revista ilustrada. Belém. 01/03/1919.

25. MAGDA, Maria de. A moda. A Semana: revista ilustrada. Belém. 01/03/1919.

26. MINOIS, Georges. História do Riso e do Escárnio. São Paulo: Unesp, 2003. P. 478.

27. MINOIS, Georges. História do Riso e do Escárnio. São Paulo: Unesp, 2003. P. 481.

28. MAGDA, Maria de. A moda. A Semana: revista ilustrada. Belém. 01/03/1919. 
necessário a "Providência o desejo misericordioso de evitar gastos desnecessários", na medida em que a falta de dinheiro era comum, em virtude da crise econômica vivida no Pará. Razão pela qual não se compreendia ver um chefe de família empenhando, no "siphon dum lança-perfumes" ou mesmo num saco de confete afina, os parcos recursos da família "mal protegida de roupas"29. E a loucura da época conduzia a excessos dessa ordem.

Vale destacar, como os códigos de Posturas ordenavam o comportamento social, atingindo, inclusive a esfera privada, nos festejos carnavalescos os maus hábitos voltavam ao centro da cidade. Por isso, o carnaval, em muitos momentos, mostrava-se como um elemento necessário a ser controlado pela administração pública, por isso muitos foram arrastados para os interiores dos salões e clubes sociais, frequentados por uma elite que se queria "moderna".

A partir daí, confrontando os interesses do carnaval, mesmo com o posicionamento diferente de Maria de Magda, Manuel Lobato utilizava-se de um fato no que o definia como "um cidadão de boas aparências", o qual vivia nos limites "honestos da integridade conjugal", por não poder, ainda que o quisesse, transpor a margem estreitíssima do orçamento doméstico. Destacava-se por ser um marido exemplar, pois trazia para o lar todo o fruto de seu trabalho. Nada desperdiçava do ordenado adquirido. Apesar de não sabermos a profissão do homem, tinha um emprego, o que por si garantia um ordenado no final do mês, por isso, podemos considerá-lo como privilegiado nos anos de 1920, em virtude da falta de empregos, ocasionado pela forte crise econômica vivida na região. Enquanto a sua esposa, mulher da "boa raça tapuya herdara o comodismo negligente, que amolenta a criatura e a torna sóbria em todos os atos" ${ }^{\prime 30}$. Este tipo de consideração acerca das mulheres descendentes de indígenas era muito comum, mostrando de certo o preconceito em relação aos hábitos sociais das mesmas, por parte dos intelectuais amazônicos.

Talvez, por isso, uma vez satisfeito o estômago, não lhe apareciam os "perturbadores" sonhos de luxo, que embriagavam as mulheres induzindo-as às práticas reprováveis. Os filhos, por seu turno, cresciam seguindo as regras da mãe, ou seja, sem preocupações de qualquer ordem. Outro elemento importante nas considerações de Manuel Lobato ficou por conta da ideia predominante na qual apenas as mulheres, nos primeiros anos do século XX, eram as responsáveis pela educação dos filhos. Vale ressaltar ainda, diante do quadro apresentado sobre a família, por Lobato, considerou, "feliz aquela gente, tanto era do agrado de todos a sorte". Certa vez, porém, o marido foi convidado, por um amigo, para participar das "correrias desordenadas da avenida da República, num domingo gordo" ${ }^{\prime 31}$. Foi sozinho, porque a mulher não o quisera acompanhar.

29. LOBATO, Manuel. A Semana. A Semana: revista ilustrada. Belém. 08/03/1919.

30. LOBATO, Manuel. A Semana. A Semana: revista ilustrada. Belém. 08/03/1919.

31. LOBATO, Manuel. A Semana. A Semana: revista ilustrada. Belém. 08/03/1919. 
-Vai, filho. Não the acho graça, e sei que me vou aborrecer solenemente. E depois, em saindo dos chinelos, não paro de ver estrelas, qualquer que seja a hora do dia.

-Só, também não quero ir.

-Porque? Teu amigo foi gentil contigo, não tens direito a recusa.

Havia tanto sossego de espirito da parte de sua mulher e o argumento era tão convincente, visto como seguia a linha de seus desejos, que ele não pode deixar de aceder, para não a desgostar.

Foi. O amigo dispunha de vinténs vadios na algibeira, e não regulava o meio de empregá-los ${ }^{32}$.

Em princípio, observara a tudo de modo transviado e o chefe de família andou com a tímida incerteza do estreante. Foi preciso insistir muito para que aceitasse qualquer favor. "- Vamos brincar, rapaz dizia-Ihe o outro". Todos sabiam da condição financeira do homem e o amigo que o convidou afirmou "tudo deve correr por minha conta". O convidado estava ciente, "mas só vim para olhar...". Como o anfitrião mostrou-se disposto a ver o seu amigo se divertir insistiu, de sorte que, pouco a pouco, acabou por pedir os elementos que lhe eram indispensáveis à brincadeira.

Veio a hora do jantar. E aquele chefe de família, era parco, mas sadio, juntou-se aos demais. Por outro lado, a esposa o esperava e com o avançar da noite, bem como as crianças dando sinal de sono, serviu a refeição sem a presença do dono da casa, o que neste contexto, representaria uma afronta ao chefe da família. Depois do jantar, os filhos e a esposa buscaram cada qual a "tipoia amiga", à espera da luz do dia seguinte. Não sabiam dormir de outra maneira. Neste momento, o ausente procurou o seu "quinhão na mesa farta do amigo, numa sala reservada do hotel". A varanda era convidativa e a "companhia de entusiasmar". Contudo, acostumado a presença da casta esposa, o encontro, no primeiro instante, Ihe pareceu chocante. A impressão, porém, teve de modificar-se com o "uso e abuso dos vinhos", de sorte que até o fim do jantar, destacava-se como o convidado menos recatado e mais comunicativo. Fez piruetas e discursos; profanou beijos e abraços. Excedeu-se de tal forma. O amigo ficou aterrorizado e teve dificuldades de conduzi-lo de volta à casa.

Chegando em casa, encontraram a porta fechada. Enquanto não vinham abri-la, o chefe de família continuava desatinado, vibrando na ponta dos pés, fazendo a vizinhança acorrer curiosa, às janelas. "Um escândalo!"³3. Aqui consideramos o que Minois denomina de "satisfação de partilhar os prazeres vulgares de seu inimigo de classe $\mathrm{e}^{\prime 34}$, ou seja, o convite partiu de alguém abastado e assegurou ao

32. LOBATO, Manuel. A Semana. A Semana: revista ilustrada. Belém. 08/03/1919.

33. LOBATO, Manuel. A Semana. A Semana: revista ilustrada. Belém. 08/03/1919.

34. MINOIS, Georges. História do Riso e do Escárnio. São Paulo: Unesp, 2003. P. 494. 
homem de família a possibilidade de diversão, no entanto os seus comportamentos mostraram-se aberrantes, pois produziu do bêbado "o cômico carnavalesco".

E quando a chave rodou "áspera na velha fechadura" o infeliz, perdendo o equilíbrio, foi cair aos pés da esposa aterrorizada", que imediatamente indagou, mas o,

-Que é isso?

-Não é nada, há de passar -responderam-lhe.

E do chão, onde o desgraçado empregava esforços para erguer-se, murmurava:

-Mulher, dá cá dinheiro. Quero voltar, o bródio estava bom.

-Dinheiro? Mas vem ver como a última de nossas filhas arde em febre. Deitou-se bem. Mais tarde notei que estava agitada. Fui vê-la. Queimava.

-Que tem isso? -regougava o outro. Está doente? Que morra. Depois de morta há de haver quem faça o enterro. Eu quero é a pandega. Vai ver o dinheiro! ${ }^{35}$

A quadra carnavalesca, na opinião de Lobato tinha a uma força enorme, capaz, inclusive de deturpar um homem de família, e diante do cenário festivo apresentado, não mediu esforços para tirar da mulher os parcos recursos, bem como não considerou o estado de saúde dos filhos, de modo que, cambaleante, saiu novamente para prosseguir a "faina carnavalesca". Ao voltar à casa na quarta-feira de cinzas, com os olhos "inchados de sono e o rosto maltratado dos efeitos do álcool"36, encontrou a esposa desmaiada e a filha morta.

O final trágico revelou o quanto o homem, diante dos prazeres promovido pelo carnaval, não ligou para a situação precária que encontrou a família. Podemos considerar, diante do encerramento da crônica, o chefe de família, encantado com a situação nada comum em sua vida e, após o convite do amigo, desejou de forma profícua participar dos festejos, mas não tinha recursos financeiros. Contudo, na opinião do cronista, a esposa foi vista como a responsável pela situação econômica do marido, haja vista que não tinha intenções maiores, como os "perturbadores sonhos do luxo" ${ }^{\prime 37}$, e por essa razão, quando foi convidado pelo amigo para ir aos blocos carnavalescos, apesar de a princípio ter hesitado, o homem, diante dos argumentos da esposa, ficou à vontade para participar, perdendo, com isso, a razão diante das festas de Momo. Novamente voltamos as considerações de Minois ao apontar a dimensão "de flagelo público" que o álcool adquire no

35. LOBATO, Manuel. A Semana. A Semana: revista ilustrada. Belém. 08/03/1919.

36. LOBATO, Manuel. A Semana. A Semana: revista ilustrada. Belém. 08/03/1919.

37. LOBATO, Manuel. A Semana. A Semana: revista ilustrada. Belém. 08/03/1919. 
início do século XX, onde o riso produzido pelos bêbados não inspirava mais as palavras e as canções, pois a partir de então passou a considerar os aspectos exteriores do bêbado, já que foi "transformado num pobre-diabo derrisório" 38 .

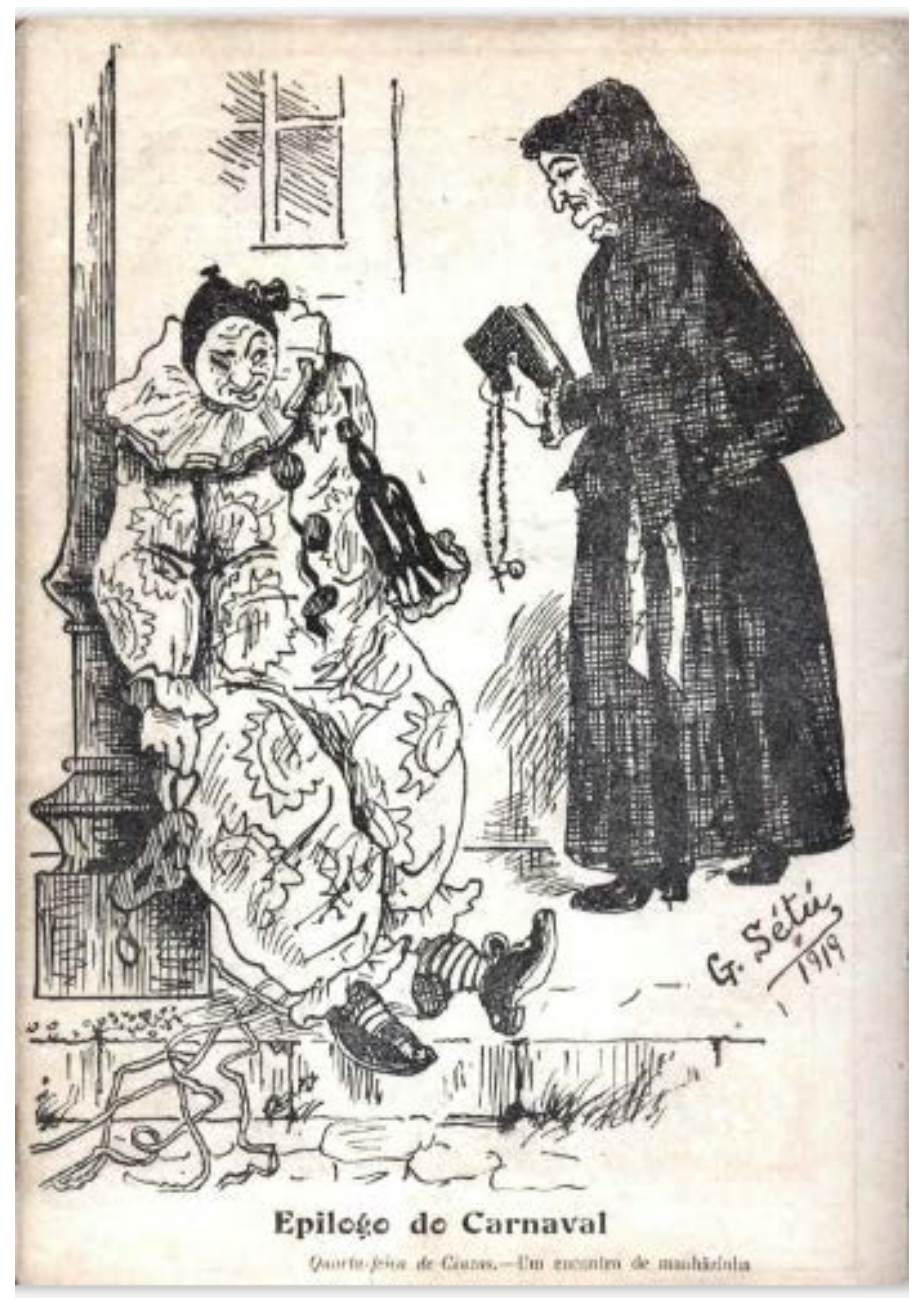

Figura 3. A Semana: revista ilustrada, Belém, Ano 1, 50, 08/03/1919.

A imagem 3 publicada no mesmo número da revista demonstra a presença de dois elementos importantes, o sagrado e o profano. Essa caricatura, corrobora com

38. MINOIS, Georges. História do Riso e do Escárnio. São Paulo: Unesp, 2003. P. 495. 
a construção da crônica de Manuel Lobato, ao mostrar o Arlequim completamente perdido, resultado dos efeitos carnavalescos, pois bêbado não tem compostura. Sendo assim, o estado produzido no homem pelo álcool é "tão destrutivo quanto às bombas de Ravachol"39. O Arlequim, por sinal, carrega em suas mãos a garrafa de vinho, já a máscara não faz mais sentido, por isso foi tirada. Agora seria possível a todos saber quem estaria por trás daquela fantasia. Em contrapartida, a freira olha para a cena, mas sabe que aqueles atos eram normais, naquelas quartas feiras de cinza. Ressalte-se no estado em que se encontrava, o Arlequim não leva em consideração os elementos essenciais de uma sociedade. Como bem define Georges Minois, tudo passa, ou seja, a "família, a religião, a polícia, o Estado, o governo, o trabalho, a cultura, a paz, a guerra, até a pátria, mesmo que haja ébrios patriotas" ${ }^{\prime 40}$.

Diante do cenário, vivido na cidade de Belém, Manuel Lobato e Maria de Magda demonstravam, com as suas análises um vasto conhecimento sobre a história do carnaval. Realizando, por isso, uma construção de como essa festa poderia ocorrer, dando inclusive sugestões para a sua realização. Maria de Magda foi além ao partir dos parâmetros definidos pela moda. Construiu sua crônica abordando temas diversos, e ligando o carnaval com a relevância adquirida pela moda. Afinal de contas, esta se tornou um elemento essencial, de modo que foi possível perceber a sua atuação nos mais diversos debates sociais trazidos à baila pelas páginas dos magazines. Não à toa Gilda de Melo e Souza ${ }^{41}$ destaca não se pode estudar a arte da moda, de modo isolado do seu contexto, pois é carregada de injunções sociais, porque os elementos estéticos não podem ser os únicos analisados, ou seja, para se compreender a riqueza de informações trazidos pela moda, faz-se necessário inseri-la no seu momento e no seu tempo, buscando, assim descobrir quais ligações mantém com a sociedade, mostrando de forma marcante, em especial, nas figuras femininas.

O que isto quer dizer afinal? No caso da relação estabelecida entre o carnaval e a moda existe uma conexão entre os aspectos construtivos da moda, a seu tempo, e as narrativas trazidas pelas fontes. Neste caso, quando mencionamos a moda masculina, por exemplo, ela foi perdendo gradativamente os traços exibicionistas, e imperando cada vez mais os tons de preto e cinza. Ou seja, nos anos de 1920, houve claramente uma oposição aos trajes femininos enriquecidos com as rendas, enfeites, babados e fitas, como evidenciado no caso da figura 2. As cores, principalmente o branco e os tons claros estampavam as peças femininas. Evidenciando, assim a existência de uma nítida conotação entre os valores masculinos e femininos, pois os homens com suas vestimentas deveriam incorporar a seriedade e o ascetismo nas sóbrias roupas escuras, por seu turno as mulheres incorporavam, com suas roupas claras, a docilidade da esposa e mãe.

39. MINOIS, Georges. História do Riso e do Escárnio. São Paulo: Unesp, 2003. P. 494.

40. MINOIS, Georges. História do Riso e do Escárnio. São Paulo: Unesp, 2003. P. 494.

41. SOUZA, Gilda de Mello e. O Espirito das Roupas: A Moda no século XIX. São Paulo: Companhia das Letras, 1987. 
Outra revista importante para a história da Amazônia: a Guajarina, por seus colaboradores, trouxe informações sobre a moda do nu, considerada perfeitamente higiênica e moral. Este tipo de moda progredia rapidamente. Os médicos quando reencarnassem teriam um desapontamento, porque não encontrariam os homens que procuram e das mulheres nem mesmo os vestidos ${ }^{42}$. O texto publicado no periódico mostrava a opinião de um homem sobre a moda, precisamente a feminina, criticando a forma como vinha sendo atualizada para atender as necessidades da mulher na cidade de Belém, do século passado, de modo que não fazia sentido a manutenção de uma moda a qual atrapalhasse o desenrolar da vida moderna belenense, pois a mulher, por exemplo, encurtou a saia para facilitar a subida nos bondes.

O mais interessante é que os desenhistas de modas, segundo Hobsbawm destacavam-se como um grupo notoriamente não analítico, mesmo assim, conseguiam prever acontecimentos futuros. Para Eric Hobsbawm é possível comparar os desenhistas aos "profetas profissionais", na medida em que "essas artes previram o colapso da sociedade liberal burguesa com vários anos de antecedência" ${ }^{\prime 3}$. Vale lembrar, diversos elementos, como as artes, a arquitetura, a indústria, marcaram a ideia de sociedade "moderna", pois os idealizadores estavam ativos e produtivos nestes primeiros anos do século $\mathrm{XX}^{44}$.

\section{Uma revista esportiva: conselhos para a saúde}

A revista $A$ Semana, por seus redatores, demonstrava, de várias formas, os assuntos inseridos na região amazônica, no contexto internacional. Tanto que os esportes se tornaram temas preferidos, por diversos fatores como, por exemplo, os "sportman", na teoria eram homens, com um bom preparo físico e com corpos esbeltos. Por outro lado, os esportes foram vistos como mecanismos necessários para a questão da saúde. Neste caminho, na edição de 25 de janeiro de 1919, na coluna denominada "A semana Sportiva", o redator destacou a importância das atividades físicas para as crianças.

Enfatizou que coube ao "Sport Clube" a mais velha agremiação esportiva e recreativa da cidade Belém, iniciar a tarefa de tornar realidade a prática da educação física das crianças. Lembrou até então a tentativa tinha sido esposada por vários

42. SOMBRA, Braulio. O elogio da moda. Guajarina: magazine ilustrado. Belém, $06 / 11 / 1920$.

43. HOBSBAWM, Eric. Era dos extremos: o breve século XX 1914-1991. São Paulo: Companhia das Letras, 1995. P. 178.

44. No campo das artes Hobsbawm afirma que as únicas inovações formais depois de 1914 no mundo da vanguarda estabelecida foram o dadaísmo que se transformou ou antecipou o surrealismo. E dentre os nomes que já se encontravam bastante ativos no mundo pós 1914, estava T. S. Eliot, "cuja poesia só foi publicada de 1917 em diante, já fazia parte do cenário vanguardista de Londres". HOBSBAWM, Eric. Era dos extremos: o breve século XX 1914-1991. São Paulo: Companhia das Letras, 1995. P. 179. 
clubes, mas sem sucesso e, a razão para o fracasso ficou por conta de os clubes terem adotado como atividade a prática do "foot-ball", sendo, por isso, o jogo bretão considerado inapropriado para esse fim, pois o clima amazônico não era propício.

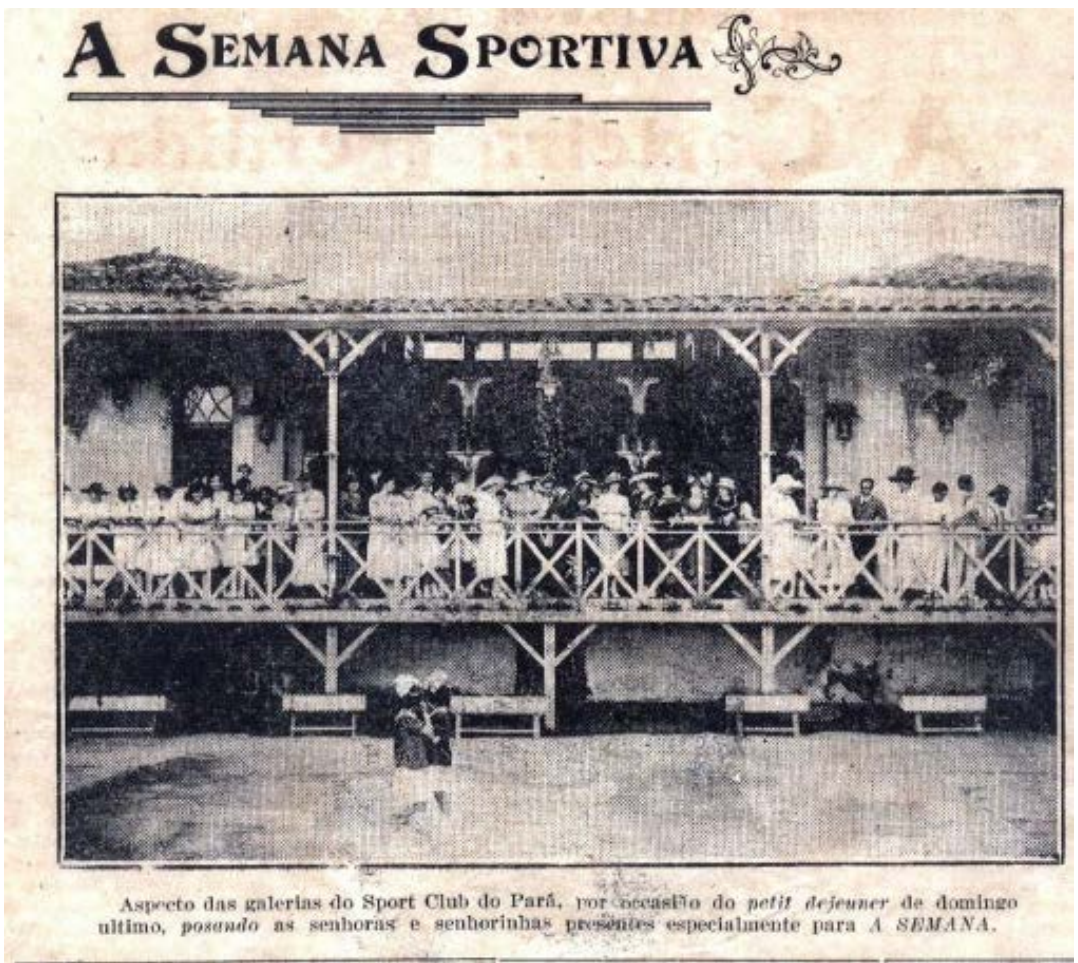

Figura 4. A Semana: revista ilustrada. Belém, Ano 1, 44, 25/01/1919.

O "Sport Club" utilizou-se, segundo os redatores, do conhecimento e da competência de diretores esportivos e instrutores entendidos no métier. Introduziu para o fim a ginástica sueca, o volleyball e outros esportes "leves", caminhando, assim "para a vitória desejada". Neste sentido, a fotografia acima mostrou a "festa de domingo último", marcada pela simplicidade bem como mostrou-se mais apropriada a homenagem que a "velha sociedade queria prestar ao tenente Benjamim Sodré, ao assumir a direção dos esportes", o evento constituiu-se numa nota "encantadora, uma vez que a parte mais bela, dessa festa, ao ar livre, foi desempenhada pelas crianças", vários exercícios e evoluções fizeram, demonstrando assim o quanto "lhes tem aproveitado a educação do corpo como cooperadora de uma sã moral e útil elemento de saúde" ${ }^{25}$.

45. A semana sportiva. A Semana: revista ilustrada. Belém, 25/01/1919. Ano 1. N 44. 
Predominava nas páginas das revistas menções ao futebol, contudo, outras atividades esportivas foram relatadas ao longo dos anos de 1920. Os redatores fizeram questão de demonstrar, também, a realização de outros esportes praticados como, por exemplo, o remo e o tênis. Nestas atividades esportivas se destacavam a presença de homens e mulheres, elegantemente vestidos. Ressalte-se que estes esportes, em sua maioria, eram praticados aos domingos, criando uma atmosfera diferencial para os membros da elite paraense, os quais saiam às ruas com suas belas roupas a fim de, em muitos casos, exibir-se para os demais.

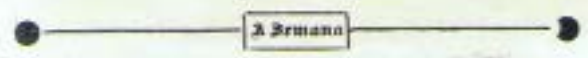

BELEM AOS DOMINGOS
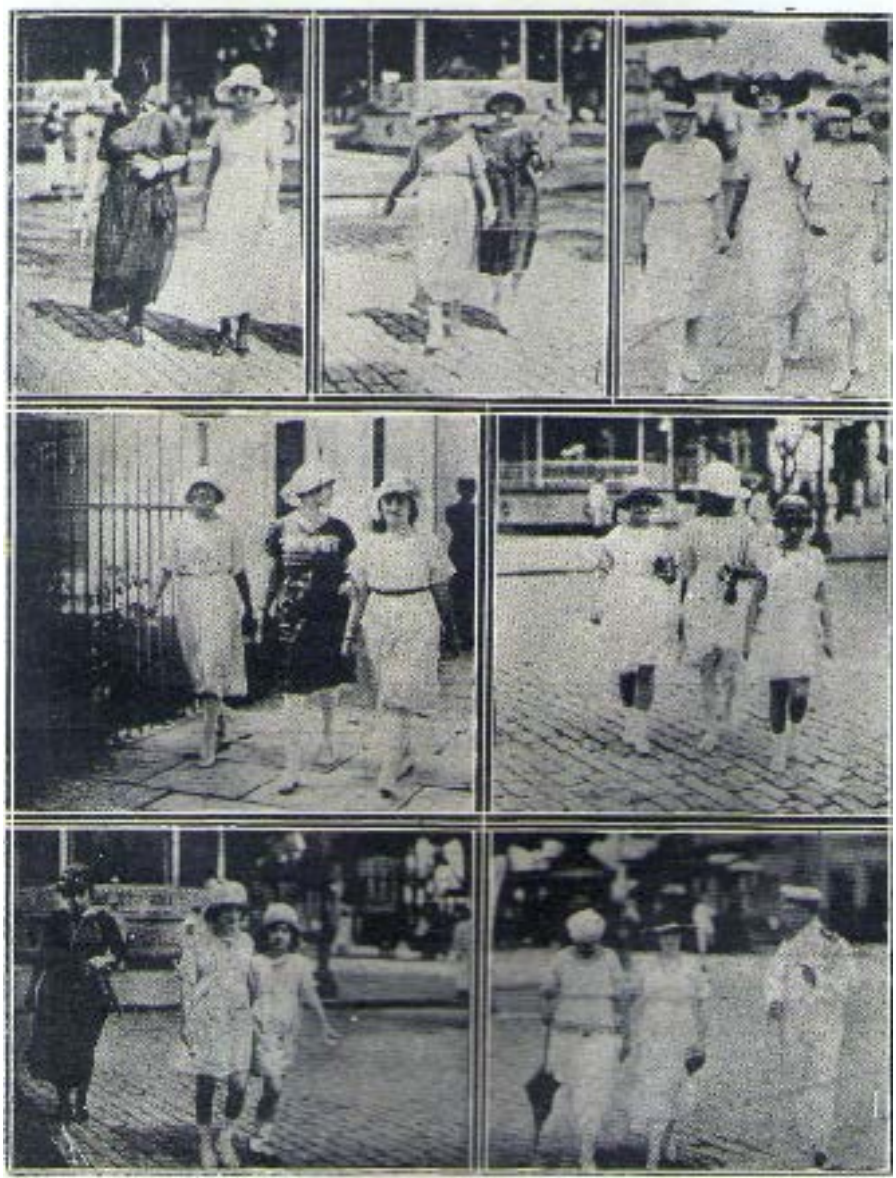

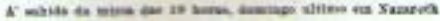

Figura 5. A Semana: revista ilustrada. Belém, Ano 3, 127, 04/09/1920. 
Nas fotografias fica evidente o predomínio do "belo sexo" pelas ruas da cidade. Em muitos casos, os registros eram realizados no momento em que as senhoras e senhoritas saiam das igrejas. No entanto, em muitas situações, vinculavam suas atividades a vida esportiva da cidade. Os "endomigados" 46 predominavam nas ruas da cidade, mostrando-se enquanto uma elite dominante ao criar uma espécie de obstáculo àqueles que não preenchiam o padrão pré-determinado pela sociedade paraense do período.

Além das fotografias os redatores procuraram introduzir nas páginas do magazine elementos, ao mesmo tempo, capazes de marcar certa inovação tecnológica, e que foram responsáveis por provocar nos seus leitores certo riso. Neste caso, as caricaturas apesar de serem consideradas, para alguns, como uma arte "bizarra" 47 e por si capaz de provocar exageros nos seus representados, ganhou espaço, pois, os semanários, passaram a contar com um número de artistas dedicados à sua arte caricatural. Como esse tipo de elemento passou a compor a produção da A Semana, constantemente, o magazine fazia buscas entre os seus "confrades" sobre novos talentos para atender a demanda das redações.

\section{Uma revista debochada: humor nas páginas do magazine}

Diversos mecanismos foram introduzidos, nas páginas do semanário, a fim de assegurar aos seus leitores uma maneira leve e de fácil compreensão. Justamente nas revistas os caricaturistas ganharam espaço cada vez maior. Muitos formavam interpretações de como percebiam a sociedade do seu tempo, mostrando com as suas imagens uma cidade marcada por diversos problemas. Mas, muitos iam além, na medida em que levou ao público leitor maneiras de conceber a política brasileira. Como no caso da imagem abaixo, onde a representação de Barbosa Rodrigues apresentado como uma noiva fantasiada, dando, com isso, ao homem ligado a economia, um ar de sofrimento, pela maneira como o mesmo foi representado.

Sendo assim o riso funcionava como algo capaz de liberar as emoções reprimidas. Segundo Elias Thomé Saliba "o riso compensava, em seus efeitos, o dispêndio continuo de energia exigido para manter as proibições que a sociedade impõe e os indivíduos internalizam ${ }^{\prime 48}$, justamente, por isso, as revistas passaram a contar com este tipo de mecanismo de divertimento. Sendo assim, as imagens caricaturais demonstravam o quanto se ganhava, em termos de divertimento, com essas representações.

46. A expressão "endomigados" era utilizado para fazer referência às pessoas que tomavam as ruas da cidade de Belém, aos domingos, com suas melhores roupas. Primeiro iam a igreja e depois saiam para se exibir. Com isso os periódicos aproveitavam para publicar os instantâneos nas suas páginas.

47. A caricatura ganhava cada vez mais espaço. No entanto, para os redatores essa era uma "arte da bizarria", como afirmado por Rocha Moreira.

48. SALIBA, Elias Thomé. Raízes do riso: a representação humorística na história brasileira: da Belle Époque aos primeiros tempos do rádio. São Paulo: Companhia das Letras, 2002. P. 23. 


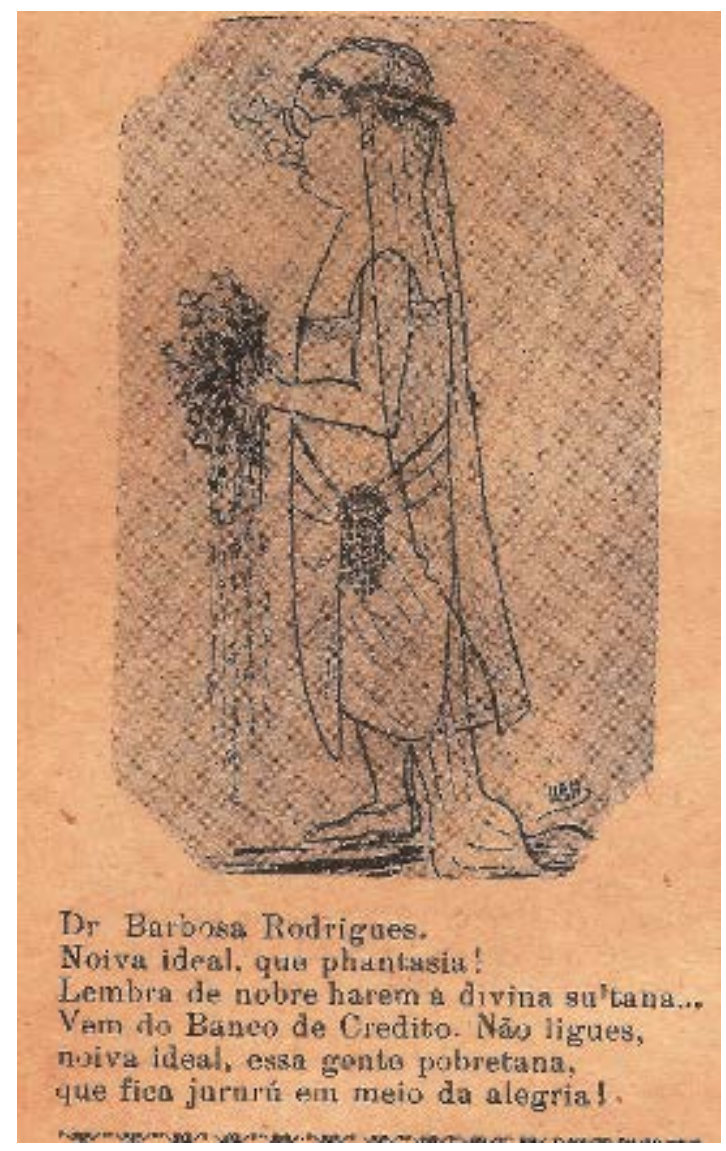

Figura 6. A Semana: revista ilustrada. Belém, Ano 6, 306, 01/03/1924.

No mesmo número, os redatores apresentaram outra imagem caricatural, de certo modo, ofendia um homem e a instituição católica. Mostrando inclusive uma crítica forte aos símbolos religiosos. Vale considerar, o humorismo construído pelos lápis dos caricaturistas, não reconheciam heróis, mas possibilidades de representar, homens e instituições de modo a aproximar dos leitores a maneira como viam a sociedade. Saliba mais uma vez fornece informações relevantes para se compreender o pensamento do homem humorista, pois "procura apreender todos os lados da realidade, exercitando ao máximo, e levando ao limite, a sua percepção e o seu sentimento contrário" ${ }^{\prime 4}$.

49. SALIBA, Elias Thomé. Raízes do riso: a representação humorística na história brasileira: da Belle Époque aos primeiros tempos do rádio. São Paulo: Companhia das Letras, 2002. P. 27. 


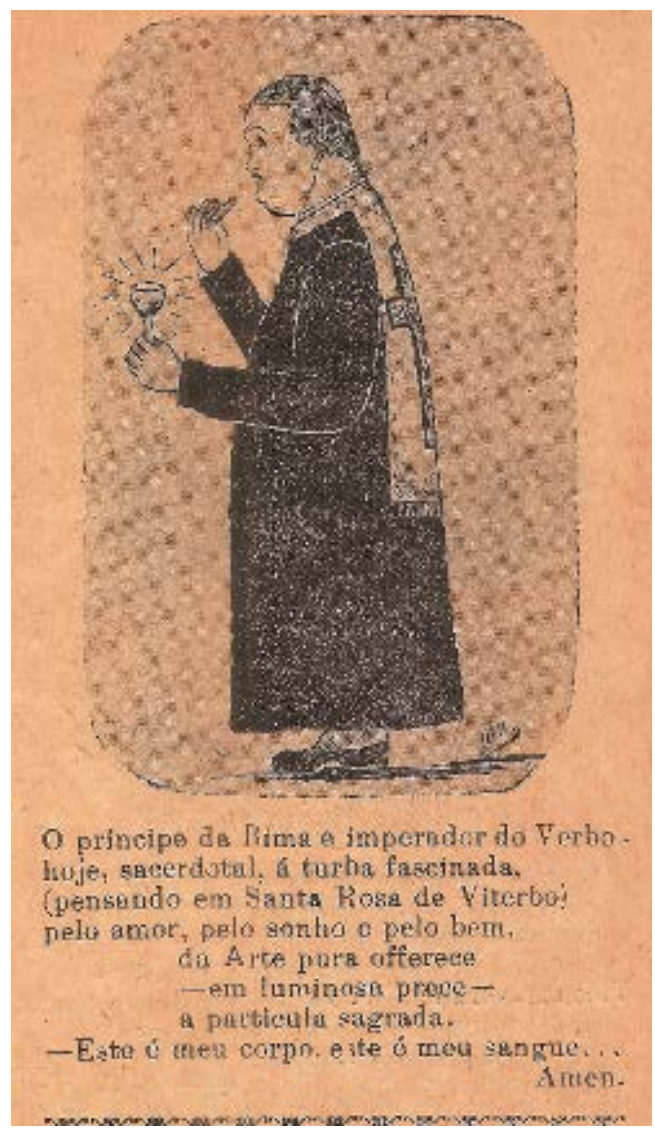

Figura 7. A Semana: revista ilustrada. Belém, Ano 6, 306, 01/03/1924.

A representação do padre com os símbolos da religião católica, mostram como os humoristas não acreditavam em muitos desses valores, mas os viam com a possibilidade de fazer o seu leitor rir. Minois destaca que os "dogmas cristãos são reduzidos a derrisão, em particular a encarnação, a trindade, a transubstanciação a imaculada concepção" ${ }^{\prime 50}$, isto quer dizer, o humorista buscava, com isso, produzir um riso libertador justamente no lugar onde a ordem estabelecida pela instituição Igreja condenava as afrontas cometidas contra ela. Por isso, era desafiador ao caricaturista desafiar uma instituição que, mesmo no início do século XX, desempenhava um papel importante, em relação a moral.

50. MINOIS, Georges. História do Riso e do Escárnio. São Paulo: Unesp, 2003. P. 506. 
Diversos temas fizeram parte do dia a dia da revista. Alguns muitos debatidos, outros eram novidades. Por exemplo, o espiritismo ${ }^{51}$, nos anos de 1920, em Belém, esteve presente nas páginas dos principais jornais e revistas da cidade. A capital do Pará mostrava-se receptiva para as novidades proporcionadas pelo século XX. A edição da revista $A$ Semana, de 02 de abril de 1921, apresentou a imagem caricatural de Andrelino Cotta, considerado pelos seus contemporâneos como um dos mais "brilhantes caricaturistas" 52 presente na história do periódico ao longo dos anos de 1920.

Pela representação é possível ver um ambiente no qual as atividades se realizavam. A produção foi pautada na reportagem do jornal A Província do Pará, ao chamar atenção para o lugar onde ocorreu a sessão espírita, ao mesmo tempo relacionou o ato a residência de uma "distinta família da nossa sociedade" Para os redatores do jornal a médium fez a previsão do acidente que ocorreria com o navio. Porém, as críticas realizadas contra a sessão partiram dos Padre Dubois ${ }^{54}$ o qual ressaltou a necessidade de avisar a polícia e ao capitão do porto sobre aquela previsão. Por sinal, segundo a nota do redator da revista $A$ Semana os conselhos do padre não foram seguidos, pois a previsão tinha sido divulgada somente após o ocorrido.

51. Para saber mais sobre o tema em Belém ver: EVANGELISTA, Sheila Izolete Mendes. O arraial do espiritismo: a médium Anna Prado, positivistas, espíritas e católicos em Belém (1918-1923). 2012. 105 f. Dissertação (Mestrado) - Universidade Federal do Pará, Instituto de Filosofia e Ciências Humanas, Belém, 2012. Programa de Pós-Graduação em História Social da Amazônia.

52. MOREIRA, Rocha. Caras e caretas. A semana: revista ilustrada. Belém, 02/07/1921.

53. Espiritanças. A Semana: revista ilustrada. Belém, 02/04/1921.

54. “Florence Dubois nasceu, no dia 12 de novembro de 1878 em Aix' d'Aigillon, norte da França. Iniciou seus estudos no colégio dos Lassalistas de Bouges, e ingressou no seminário Menor do Barnabitas, aos 15 anos. Formou-se bacharel em Retórica na Sorbonne de Paris aos 19, e ordenou-se sacerdote aos 19, no dia 10 de março de 1902, em Bruxelas. Sua primeira visita ao Brasil aconteceu aos 25 anos. Em 1905 o religioso chega ao Pará, lugar em que desejava continuar o trabalho missionário no município de Gurupi, que faz divisa entre o Pará e o Maranhão. Na chegada, Padre Dubois conhece a aldeia dos índios Tembés do Alto-Guamá, Bragança e depois o Rio de Janeiro, onde realizou a fundação dos Barnabitas na então Capital Federal. Em outubro do mesmo ano, Padre Dubois se junta à comunidade de Nazaré. Belém se tornara o seu grande destino, escolhido para desenvolver suas atividades pastorais, interrompidas em 1915, período em que fora convocado para servir no front, como capelão e padioleiro (maqueiro) na Primeira Guerra Mundial (1914-1918), durante quatro anos."

Religioso muito popular no Estado. Bispos de vários estados do País o convidavam para conferências, pregações e retiros. Vigários dos mais distantes lugares faziam questão de sua presença para presidir festas de santos e ouvir suas reflexões. Escreveu ativamente nos periódicos e semanários da época. Faleceu em Paris em 11 de outubro de 1964. Informações disponíveis em: http://mosqueirando.blogspot.com.br/2013/05/janelas-do-tempo-padre-dubois. html. Acesso em 19/02/2018. 


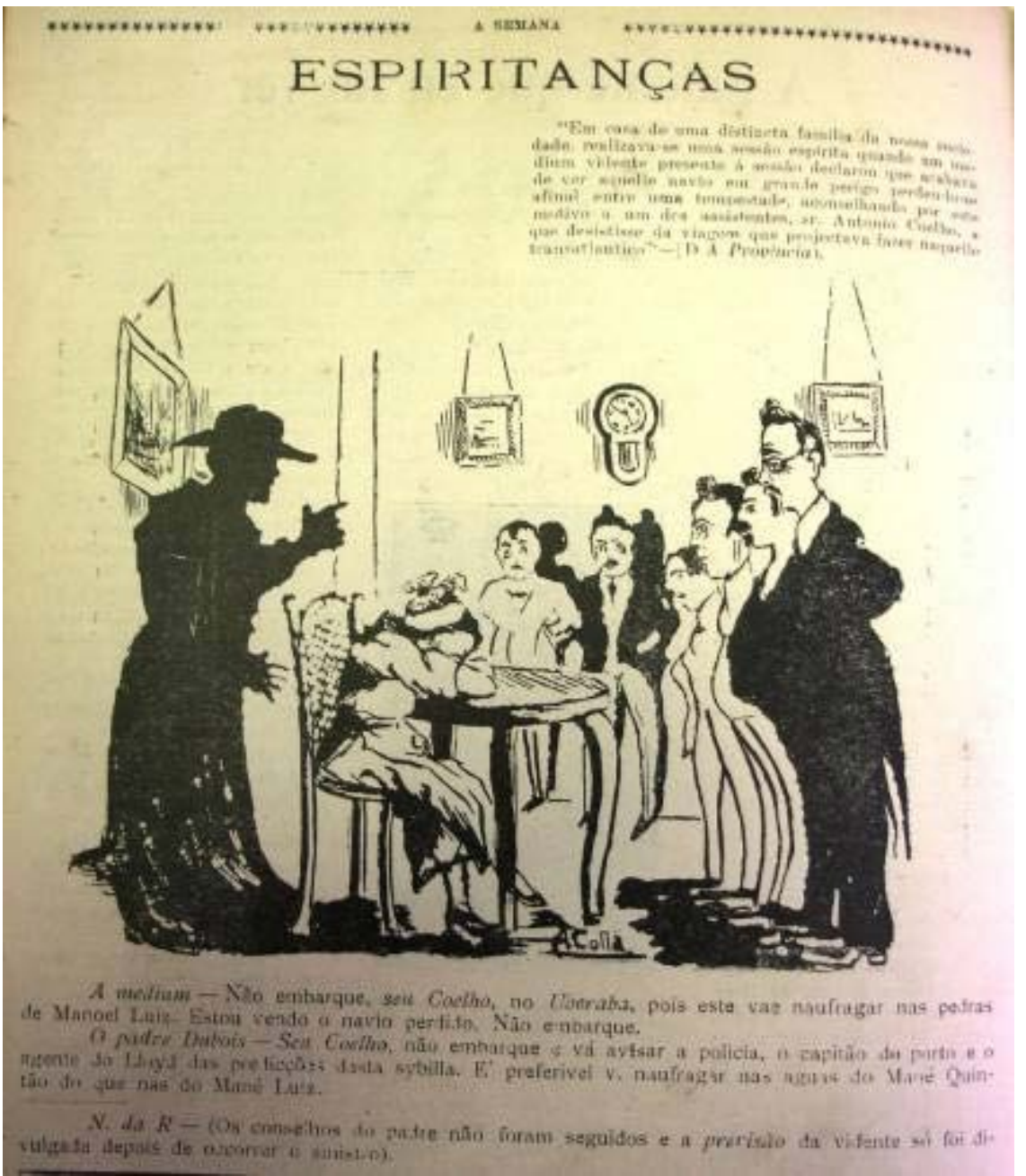

Figura 8. A Semana: revista ilustrada. Belém, Ano 4, 156, 02/04/1921.

\section{Considerações finais}

A intensa produção semanal saída das páginas do magazine $A$ Semana demonstram o quanto esse periódico proporcionou a sociedade belenense um conjunto de temas os quais valorizavam os diversos aspectos vivenciados no cotidiano regional. Ao mesmo tempo, possibilitou a inserção de temas relevantes ao apresentar aos leitores paraenses informações de cunho regional, nacional e 
internacional. Destacando que, no momento de circulação da revista de forma contínua, mostrou o quão necessário era para a região contar com esse tipo de produção.

Ressalte-se diversos nomes atuaram neste magazine. Muitos inclusive criaram a sua condição de intelectual graças a participação na revista, na condição de colaboradores do periódico. A quantidade de intelectuais que se disponibilizaram para alavancar um número maior de leitores para a revista, possibilitaram compreender o tipo de mercado o qual se mostrava favorável, não apenas aos intelectuais, mas também aos homens de negócio que viram nestes espaços a possibilidade de divulgarem de forma contundente os seus produtos.

Manuel Lobato ao criar o magazine percebeu as possibilidades de ver as suas opiniões chegarem a um número considerável de leitores. Mas para que a sua revista pudesse ser aceita no meio social belenense, era necessário contar com os mais diversos sujeitos. Isto é, desde quem escrevia as crônicas, passando pelos "moleques" responsáveis por saírem às ruas aos sábados depois das $18 \mathrm{~h}$ para vender "o importante semanário" na cidade. Por essa razão o conjunto social composto pela redação e a sua logística propiciaram a divulgação do magazine na capital do Pará.

Portanto, as revistas que circularam, em Belém, tinham o público leitor, muitas vezes bem inferior ao noticiado. Diante disso, era necessário ampliar a sua atuação, mesmo que fosse recorrendo a temas comumente debatidos em jornais, como a moda e o carnaval os quais tinham espaços privilegiados ao longo do ano. Assim, A Semana com sua vida longa, mostrou-se importante para a história da Amazônia, pela relevância dos temas que circulavam e chegavam aos olhos da elite e ouvidos daqueles que não sabiam ler, mas em muitos momentos paravam para folhear e ver as imagens publicadas, como as fotografias e as caricaturas.

\section{Referências Bibliográficas}

Baxandall, Michel, Padrões de intenção: a explicação histórica nos quadros. Companhia das Letras, São Paulo, 2006.

Berman, Marshall, Tudo que é sólido desmancha no ar: a aventura da modernidade. Companhia das Letras, São Paulo, 1986.

Castro, Raimundo Nonato de, "Do carnaval ao social: a caricatura de Andrelino Cotta - 1919-1928". Temporalidades, 7 (1), 2015, pp. 306-325.

Evangelista, Sheila Izolete Mendes, $O$ arraial do espiritismo: a médium Anna Prado, positivistas, espíritas e católicos em Belém (1918-1923). 2012. 105 f. Dissertação (Mestrado) - Universidade Federal do Pará, Instituto de Filosofia e Ciências Humanas, Belém, 2012. Programa de Pós-Graduação em História Social da Amazônia. 
Hobsbawm, Eric, Era dos extremos: o breve século XX 1914-1991. Companhia das Letras, São Paulo, 1995.

Hobsbawm, Eric, A era dos impérios 1875-1914. Paz e Terra, São Paulo, 2012.

Junior, Rembrandt, "Chispas". A Semana: revista ilustrada, Belém, 18 de janeiro de 1919.

Lobato, Manuel, "A Semana". A Semana: revista ilustrada, Belém, Ano 1, 49, 1 de março de 1919.

Lobato, Manuel, "A Semana". A Semana: revista ilustrada, Belém, Ano 1, 50, 8 de março de 1919.

Magda, Maria de, "A Moda". A Semana: revista ilustrada, Belém, Ano 1, 49, 1 de março de 1919..

Martins, Ana Luiza, Revistas em revista: Imprensa e práticas culturais em tempos de República, São Paulo (1890-1922). Editora da Universidade de São Paulo, Fapesp, São Paulo, 2008.

Minois, Georges, História do Riso e do Escárnio. Unesp, São Paulo, 2003.

Moreira, Rocha, "Caras e caretas". A semana: revista ilustrada, Belém, 169, 2 de julho de 1921.

Saliba, Elias Thomé, Raízes do riso: a representação humorística na história brasileira: da Belle Époque aos primeiros tempos do rádio. Companhia das Letras, São Paulo, 2002.

Sombra, Bráulio, "O Elogio da moda". Guajarina, Belém, Ano 2, 20, 6 de novembro de 1920.

Souza, Gilda de Mello e, O Espirito das Roupas: A Moda no século XIX. Companhia das Letras, São Paulo, 1987.

Starobinski, Jean, As máscaras da civilização: ensaios. Companhia das Letras, São Paulo, 2001. 